\title{
Transparency in Municipalities in the Southern Region of Brazil
}

\author{
Alexandre Costa Quintana \\ Universidade Federal do Rio Grande - Furg - Brazil \\ RuaChefe Carlos Araújo, 166 - Rio Grande - RS \\ Brasil - CEP 96206.210 \\ FláviaVerônica Silva Jacques \\ Universidade Federal do Rio Grande - FURG - Brazil \\ Rua Caramuru, 162 - Rio Grande - RS \\ Brasil - CEP 96211.500 \\ Clea Beatriz Macagnan (Corresponding author) \\ Universidade do Vale dos Sinos - UNISINOS - Brazil \\ Rua Almirante Abreu, 139/802 - Porto Alegre - RS \\ Brasil - CEP 90420.010 \\ Email: cleabeatrizm@gmail.com
}

Received: August 11, 2016 Accepted: August 28, 2016 Published: September 08, 2016

doi:10.5296/jpag.v6i3.9858 URL: http://dx.doi.org/10.5296/jpag.v6i3.9858

\begin{abstract}
Transparency in government actions strengthens the relationship between government and society. The goal of the present study was to ascertain the level of transparency of administrative information in the south of Brazil. This descriptive study, which employed statistical methodology, found a correlation between the presence of examined indicators and municipal gross domestic product (GDP). It also revealed that population; GDP and tax revenues are variables that, if jointly analyzed, can be used to aggregate municipalities that display similar behavior in terms of transparency.
\end{abstract}

Keywords: Transparency; Municipal Government; Brazilian Information Access Law 


\section{Introduction}

Transparency in government actions strengthens the relationship between government and society. On its public transparency website, the National Treasury Secretariat (Secretaria do Tesouro Nacional- STN) states that societal participation is needed to guarantee the good use of Brazil's public resources. To guarantee transparency in governmental actions, in 2000, after countless similar legislations, the federal government enacted Complementary Law n. 101/2000, known as the Fiscal Responsibility Law (Lei de Responsabilidade Fiscal), which provides a series of directives for public finance in all of its spheres.

In order to ensure social accountability, Brazil's public administration makes information about its activities available to its citizens by means of the Public Transparency Pages (Páginas de Transparência Pública), managed by the Ministry for Planning, Budget and Administration (Ministério do Planejamento, Orçamento e Gestão- MPOG) and the office of the Inspector General of the Union (Controladoria Geral da União - CGU). These pages are intended to provide a way for citizens to know how the resources obtained from tax revenues are used (Decree n. 5.482, 2005; Interministerial Ordinance n. 140, 2006).

Law n. 12.527, known as the Information Access Law (Lei de Acesso à Informação) was passed in 2011 to regulate the constitutional right of citizens to access public information on the Brazilian Union's three levels of authority: the states, Federal District and municipalities. This law marks the beginning of an important stage in Brazil's democratic consolidation and its efforts to successfully prevent corruption because it allows for greater participation by the population and for societal supervision of government actions, which leads to better public administration (CGU, 2012).

Since the issuance of Complementary Law n. 101/2000 - Fiscal Responsibility Law (FRL) and Law n. 12.527/2011 - Information Access Law (IAL), Brazilian public institutions have been going through a modernization process in relation to their supervision and the attribution of responsibility for their actions, which promote the transparency and publicity of government administrations. From this point of view, scientific research that furthers the understanding of this entire process is considered relevant. The goal of the present study was to ascertain the level of informational transparency within municipal administrations in the southern region of Brazil.For that, the study comprised the analysis the indicators of the evidences about the level of transparency of municipalities of state of Rio Grande do Sul, with population over 100.000 inhabitants, published on the Transparency Website or on the municipalities Website, totalizing 18 municipalities. As a parameter to measure the transparency level we have used the study of Laboratori de Periodisme i Comunicació per a la Ciutadania Plural da Universitat Autònoma de Barcelona, that created a set of representative indicators of information that try to identify in the Website the good disclosure of information about management of the municipalities. Further, the Websitewasanalyzed identifying the disclosure of pre-defined indicators of information of the municipalities.

Literature review on Transparency and Access Act of information in order to base this research was conducted. As delimitation, it should be stressed that the perspective of this study refers to the information available to citizens through Website of municipal 
governments. This research has not focused on the vision of the municipalities on the relevance of this disclosure.

\section{Transparencies and Accountability}

The intention of creating mechanisms to control public actions is not recent. However, the Brazilian public administration has gone through significant structural changes in this regard only in the last decade. This transition has been accomplished with the aid of information technology instruments, such as the creation of the Integrated Budgetary Data System (Sistema Integrado de Dados Orçamentários - Sidor), used by the federal administration to control its budgetary information, and the implementation of the Federal Government's Integrated Financial Administration (Sistema Integrado de Administração Financeira do Governo Federal - Siafi) and Managerial and Planning Information Systems (Sistema de Informações Gerenciais e Planejamento - Sigplan). These systems seek to provide increased security to managers, presenting themselves as modern and effective instruments to control and monitor public expenditures (Culau; Fortis, 2006; Cavalcante, 2008; Barros, 2008): “All these systems, while facilitating interactions between the government and citizens, can contribute to the promotion of democratization, allowing for greater administrative transparency and government accountability" (Prado; Loureiro, 2006, p. 356).

The increased transparency of national political activities is also connected to the minutes and notes of parliamentarian discussions available in communications media, especially the Internet, which present integral versions of political negotiations in law-making and other parliamentary activities (Barbosa, 2009). Therefore, popular participation in themes connected not only to the control of public resources but also to government policy should be stimulated. However, "effective modernization will take place only through reforms that redistribute the power resources and alter the communication channels between the public and its administration" (Motta, 2007, p. 87).

The works of Ingram and DeJong (1987), Evans and Patton (1987), Moon (2002), Laswad, Fisher and Oyelere (2005), Cárcaba and Garcia (2008) and Serrano-Cinca, Rueda-Tomás and Portillo-Tarragona (2009) attempt to prove that there is a positive relation between information transparency and the size of the public body. The study by Gallego-Álvarez, Rodríguez-Domínguez and García-Sánchez (2010), in turn, examines the determinants of the development of electronic government in 81 municipalities in various countries. This international comparison made it possible to observe whether there are significant differences among countries regarding results obtained in previous studies and those obtained in this study. The influence of the internal resources of public institutions was therefore tested. Specifically, the following factors were examined: 1) the organizational complexity of public entities; 2) the availability of financial resources; 3) the level of leverage; 4) the style of the public administration, according to the Organization for Economic Co-operation and Development (OECD) and 5) non-membership in the OECD. The following political factors were also studied: 1) representation by an ideology, 2) stability of the party in power and 3) current competition policy. Although previous studies have found that municipalities within a specific country differ in terms of the information they disclose online, the findings of this 
study suggest that internationally, municipalities follow common trends in relation to the informational content of their websites. However, as municipalities increase in complexity and acquire more funding, they begin to diverge with regard to the support provided to the development of participative dynamics and e-government.

The work of García-Sánchez, Frías-Aceituno and Rodríguez-Domínguez (2012) conducts an empirical analysis of the transparency related to social responsibility of the 109 largest municipalities in Spain, along with the determinants of these information practices. Great similarities can be observed with regard to the release of information related to strategy, council profiles and economic information. In addition, there is a high degree of correlation among these practices. Furthermore, municipalities with higher degrees of transparency regarding economic, financial and budgetary matters do not tend to focus on social issues. In contrast, there is significant compensation in terms of the volume of information disclosure related to social and environmental themes. In particular, according to the results, the disclosure of environmental information has a higher degree of independence than the disclosure of other types of information.

Countless studies on this theme can be found in the national ambit, such as the one by Platt Neto, Cruz, Ensslin and Ensslin (2007), who aimed to characterize the legal requirements and scope of the publicity and transparency principles of Brazilian public administrations, focusing on the disclosure of public accounts. Their study revealed the lawful derivation, functions and scope of the publicity and transparency principles applied to the disclosure of public accounts. It also identified the Internet as an emerging channel for the examined type of disclosure. This channel gained further importance after the passing of the Fiscal Responsibility Law and Law n. 9.755/98. In addition, the theses of Barros (2008) and Barbosa (2009) on the theme of transparency in public administration at the national level were identified (to cite only two).

Note that the proportion that public transparency increases. Causes the growth of the inspection control, knowledge, access, participation and, conversely, to reduce the opacity of government and individual rights and guarantees. Another point of consideration that the study provides an opportunity, refers to social participation as central idea of the notion of citizenship, society becomes the main part of the process of development and social advancement, power control and protection of collective interests (Pires, Scherer, Santos and Carpes, 2013).

The work of Pires, Scherer, Santos and Carpes (2013) conducted in virtual sites of municipal governments using two questionnaires, the first structured by the Court of the State of Rio Grande do Sul and the second referred to municipalities to identify practical actions undertaken by municipalities under study. Based on the results it was observed that there are many aspects to be improved, especially by the municipality of Santa Maria that, in general, does not meet the legal requirements for access to public information. On the other hand, Novo Hamburgo presents best practices of public administration, reinforcing expectations of a public administration more efficient and closer society through the dissemination of public information, promoting transparency and expansion of control and supervision breaking thus 
with culture of administrative secrecy.

Transparency - even if it is directly derived from the constitutional principle of publicity encompasses, as a broader concept, the disclosure of reliable, relevant, timely and comprehensible information, which can support the process of social control by society. Transparency requires more than just presentation to the public or being seen by an ever-increasing number of people; it has to do not only with the availability of information but also the truth of what is conveyed (Barbosa, 2009).

The process of public transparency in Brazil is likely also influenced by the recent convergence of the accounting practices applied in Brazil's public sector toward the international accounting norms, resulting from the establishment of the Brazilian Accounting Norms Applied to the Public Sector (Normas Brasileiras Contábeis Aplicadas ao Setor Público - NBCASP). The main goal of Applied Accounting in the Public Sector (Contabilidade Aplicada ao Setor Público) is to provide its users with information on achieved results, as well as the budgetary, economic, financial and physical aspects of the public entity's patrimony and its variations, thus supporting decision-making processes, adequate accountability, and the instrumentation of social control (ResolutionConselho Federal Contabilidade- CFC n. 1.128, 2008).

This restructuring and adaptation in the face of new social demands, which has made intensive use of informational resources, has significantly affected public organizations, which must now interact in complex patterns and offer more and higher quality information. Furthermore, they must answer to the demands for transparency, responsibility, participation, control and legitimization, values connected to democracy that is emerged within this Information Society (Cruz, 2010).

\section{Information Access Law}

In the last decades, increased access to the Internet has caused an information revolution. The speed, ease of access and enormous availability of information have given rise to a true Information Era. At the same time, increasingly complex information systems have been developed, aggregating databases and spatial information and interconnecting processes, economic transactions and services. These technological advances have impacted governments as well (Prado; Loureiro, 2006, p. 356).

In the light of these developments, governments have been implementing new information systems, such as websites, which allow them to disclose and make a large amount of services and information of public interest accessible. Because these systems facilitate interaction between the government and society, they can promote democratization, allowing for increased administrative transparency and governmental accountability.

Inter-ministerial Ordinance n. 140 was enacted on March 16, 2006, to standardize and provide guidelines for the information made available on the Internet by the government. It establishes that all bodies and entities of the Federal Public Administration should maintain a page entitled "Public Transparency" on their respective websites on the World Wide Web. Moreover, the ordinance requires the provision of information on the budgetary and financial 
executions, public bids, contracts, agreements and travel-related expenditures of both direct and indirect Federal Public Administration bodies. Inter-ministerial Ordinance n. 140 further addresses the presentation and language that should be employed, stating that information should be presented simply and through navigation mechanisms so that any citizen would intuitively deem. In addition, all technical content should contain some introductory text, accompanied by explanatory notes whenever necessary. The federal government's own transparency page, for example, can be found at the following URL: http://www.portaldatransparencia.gov.br/.

Law n. 12.527, known as the Public Information Access Law, was enacted in November of 2011 to reinforce Inter-ministerial Ordinance n. 140. This law affects all public bodies that are members of the direct administration of the Executive, Legislative (including the Accounting Courts) and Judiciary branches, as well as the Public Prosecutor's Office, in addition to local authorities, public foundations, state companies, mixed-economy societies and other entities directly or indirectly controlled by the Union, states, Federal District and municipalities (Art. ${ }^{\circ}$, sole paragraph, 2011).

The Public Information Access Law serves to ratify all transparency and social control initiatives conducted this far by the government in an attempt to decrease the incidence of illicit activities by its own managers, providing tools to combat corruption and foster the application of the law across the country. The government, in turn, has answered these demands with proactive measures to stimulate the spread of effective and responsible policies, but the success of these initiatives still depends on cultural changes. It is necessary and relevant to change Brazil's bureaucratic culture to create new public policy management standards, build new types of social controls and partnerships and, most importantly, increase the transparency of state actions (Souza; Rezende; Hardt, 2007).

\section{Design Research}

This study analyzed evidence indicating the levels of transparency among municipalities in the state of Rio Grande do Sul with populations in excess of 100 inhabitants, as published in the transparency or institutional website of each city hall. Municipalities with populations above 100 thousand inhabitants were chosen because they receive the largest investments in the state. It must be highlighted that the 18 municipalities with more than 100 thousand inhabitants that make up the sample represent, taken together, $48.6 \%$ of the total population of Rio Grande do Sul and 53.6\% of its GDP. The public revenues collected from these municipalities in 2012 corresponded to more than 11.2 billion reais.

The parameters used to measure transparency were taken from the study by the Laboratory of Journalism and Communication for Plural Citizenship of the Universitat Autònoma de Barcelona, which elaborated a set of representative indicators to identify, on the website of each city hall, best practices for the disclosure of information about the public entity. Before the study could take place, it was necessary to adapt some indicators and exclude others to correspond to the Brazilian reality, leading to a final number of 29 indicators. They are shown in Table 1 below: 


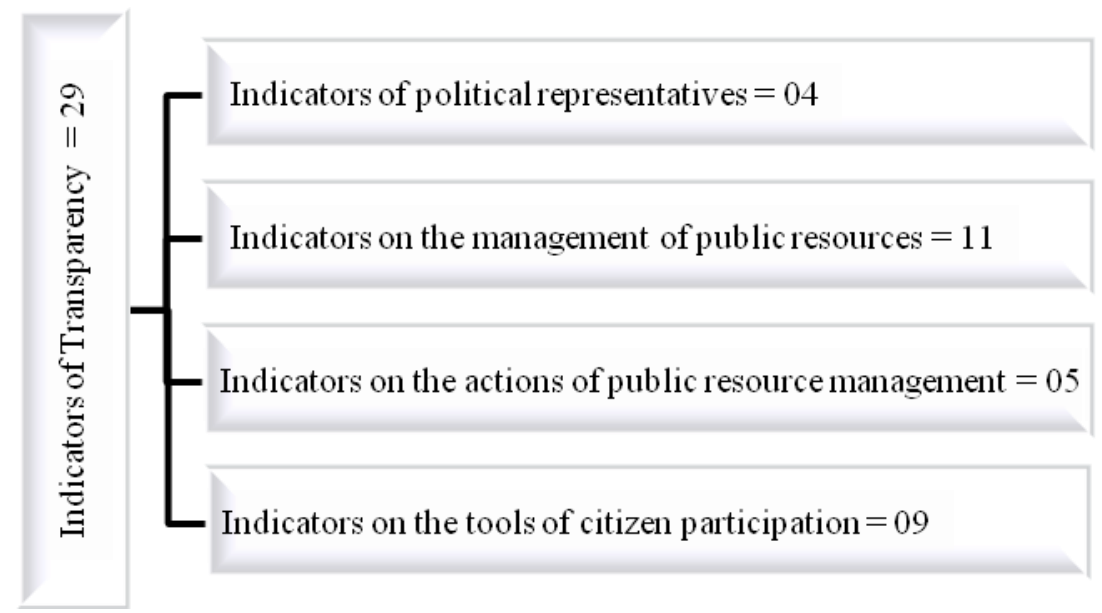

The indicators were elaborated in consideration of citizens' right to information about the public entity's functioning, the people chosen to manage the entity and the administrative resources made available for the benefit of the community. A total of 41 indicators were defined, organized into four groups, to identify the information provided by each city hall's website on which the political representatives are; how public resources are managed; the fulfillment of campaign promises and the resources and tools provided for citizen participation. This total of 41 indicators suitable for the 29 indicators was selected taking into consideration the Brazilian reality.

To develop the study, general data were first gathered for each municipality, including population, GDP at current prices, GDP per capita and collected tax revenues, to profile the examined city halls and search for correlations between these data and the indicators assessed during the survey using Pearson's linear correlation. These data were also used to search for similarities among municipalities, namely for possible clusters within the full sample. According to Martins and Theóphilo (2009, p. 130), Pearson's linear correlation is "an indicator of the strength of a linear relation between two interval variables". According to Fávero, Belfiore, Silva and Chan (2009, p. 195), cluster analysis "is a statistical interdependence technique that allows for the grouping of cases or variables into homogeneous groups as determined by the degree of similarity between individuals, based on predetermined variables". The statistical information mentioned above was obtained using the Stata12-software application.

Next, the websites of each city hall were analyzed, and disclosure of the predefined information indicators was assessed. Some points must be stressed with regard to the employed criteria. There were only two possible scores for each indicator, namely a score of one when the information is found in the city hall's website and zero when the information is not found. In some cases, the information is on the city hall website but is not easy to find; thus, a positive score was only given if the information could be accessed within four navigational steps. In the case of indicators for which more than one instance should be available, such as biographies and/or curriculum vitae, a positive score (value $=1$ ) was given if at least one such instance was found. Percentages were then computed to measure transparency levels, taking all the informational indicators used in the analysis of these 
websites into account.

\section{Analysis of Results}

To accomplish its goals, this study analyzed the websites of 18 city halls, corresponding to municipalities with populations in excess of 100 thousand inhabitants in the state of Rio Grande do Sul, according the census conducted by the Brazilian Institute of Geography and Statistics (Instituto Brasileiro de Geografia e Estatística- IBGE) in 2010. Table 1 presents the names of these municipalities and the data used in the study: population, collected tax revenues, GDP at current prices and GDP per capita. The municipalities are listed in decreasing order of population.

Table 1 - Data for surveyed municipalities

\begin{tabular}{|l|r|r|r|r|}
\hline Municipality & $\begin{array}{c}\text { Population } \\
\text { (number of } \\
\text { inhabitants) }\end{array}$ & $\begin{array}{c}\text { GDP at current } \\
\text { prices (thousand } \\
\text { R } \$ \text { ) }\end{array}$ & $\begin{array}{c}\text { GDP per capita } \\
\text { (R\$) }\end{array}$ & $\begin{array}{c}\text { Collected tax } \\
\text { revenues }\end{array}$ \\
\hline Porto Alegre & 1.409 .351 & $43.038 .100,00$ & $30.524,80$ & $4.342 .726 .813,79$ \\
\hline Caxias do Sul & 435.564 & $15.692 .359,00$ & $36.034,46$ & $1.327 .522 .416,55$ \\
\hline Pelotas & 328.275 & $4.564 .464,00$ & $13.925,47$ & $438.688 .615,00$ \\
\hline Canoas & 323.827 & $16.547 .966,00$ & $51.070,03$ & $746.249 .467,32$ \\
\hline Santa Maria & 261.031 & $4.103 .230,00$ & $15.719,56$ & $424.736 .158,05$ \\
\hline Gravataí & 255.660 & $7.081 .795,00$ & $27.689,00$ & $418.744 .220,97$ \\
\hline Viamão & 239.384 & $2.224 .541,00$ & $9.298,60$ & $231.235 .708,80$ \\
\hline $\begin{array}{l}\text { Novo } \\
\text { Hamburgo }\end{array}$ & 238.940 & $5.395 .053,00$ & $22.568,63$ & $466.888 .679,11$ \\
\hline São Leopoldo & 214.087 & $4.125 .575,00$ & $19.259,49$ & $443.778 .518,75$ \\
\hline Rio Grande & 197.228 & $7.737 .855,00$ & $39.228,07$ & $462.769 .885,96$ \\
\hline Alvorada & 195.673 & $1.473 .405,00$ & $7.528,20$ & $219.844 .250,00$ \\
\hline Passo Fundo & 184.826 & $4.551 .198,00$ & $24.618,50$ & $360.401 .559,12$ \\
\hline $\begin{array}{l}\text { Sapucaia } \\
\text { Sul do }\end{array}$ & 130.957 & $2.316 .303,00$ & $17.683,32$ & $207.613 .083,96$ \\
\hline Uruguaiana & 125.435 & $2.646 .214,00$ & $21.084,19$ & $159.120 .611,31$ \\
\hline $\begin{array}{l}\text { Santa Cruz do } \\
\text { Sul }\end{array}$ & 118.374 & $4.810 .913,00$ & $40.671,53$ & $273.455 .326,37$ \\
\hline Cachoeirinha & 118.278 & $4.363 .658,00$ & $36.888,25$ & $249.046 .934,83$ \\
\hline Bagé & $1.430 .888,00$ & $12.251,59$ & $230.510 .955,24$ \\
\hline $\begin{array}{l}\text { Bento } \\
\text { Gonçalves }\end{array}$ & $3.150 .736,00$ & $29.352,58$ & $246.490 .780,34$ \\
\hline Total & 5.000 .962 & $135.254 .253,00$ & & $11.249 .823 .985,47$ \\
\hline
\end{tabular}




\section{Macrothink}

Journal of Public Administration and Governance ISSN 2161-7104 2016, Vol. 6, No. 3

Data on population, GDP at current prices and GDP per capita were obtained from IBGE and are from 2010. Collected tax revenue data were obtained from each city hall's website and are from 2012.

\subsection{Transparency Levels of City Hall Websites}

The transparency levels of each municipality, shown in Table 2, were obtained by analyzing the informational indicators, as established in this work's methodology section.

Table 2 - Municipality transparency percentages

\begin{tabular}{|l|c|}
\hline Municipality & Percentage of positive answers \\
\hline Alvorada & $31 \%$ \\
\hline Bagé & $34 \%$ \\
\hline Bento Gonçalves & $41 \%$ \\
\hline Cachoeirinha & $48 \%$ \\
\hline Canoas & $72 \%$ \\
\hline Caxias do Sul & $55 \%$ \\
\hline Gravataí & $41 \%$ \\
\hline Novo Hamburgo & $79 \%$ \\
\hline Passo Fundo & $76 \%$ \\
\hline Pelotas & $59 \%$ \\
\hline Porto Alegre & $86 \%$ \\
\hline Rio Grande & $38 \%$ \\
\hline Santa Cruz do Sul & $41 \%$ \\
\hline Santa Maria & $59 \%$ \\
\hline São Leopoldo & $38 \%$ \\
\hline Sapucaia do Sul & $34 \%$ \\
\hline Uruguaiana & $41 \%$ \\
\hline Viamão & $10 \%$ \\
\hline
\end{tabular}

The municipalities of Porto Alegre, Canoas, Novo Hamburgo and Passo Fundo stand out on Table 2 for having higher transparency levels on their respective websites, with more than $70 \%$ disclosure of the examined indicators. The website of the Viamão municipality stands out as the least transparent, with $10 \%$ disclosure of the examined indicators, which means that it lacks basic information on all aspects of transparency and the accessibility of information to the population.

To analyze whether the computed percentages of positive scores in relation to the transparency indicators have any relation to general municipality characteristics, i.e., if there are correlations between information transparency and population, GDP, GDP per capita or collected tax revenues, a correlation analysis was performed. Computing Pearson's linear correlation coefficient performed this analysis. This revealed greater correlations between positive scores on transparency indicators and GDP at current prices, with a 0.60 index. The correlations between indicators and collected revenue, population and GDP per capita were 


\section{Al Macrothink}

$0.55,0.54$ and 0.38 , respectively.

Based on the information shown in Tables 1 and 2, a cluster analysis was performed to segment the municipalities based on the following variables: population, GDP at current prices, GDP per capita and collected tax revenues. The intention of this analysis was to ascertain, based on this segmentation, whether transparency indicators have a common profile in the generated clusters.

Variables were first normalized and then put through the cluster analysis technique, with hierarchical procedure, aimed at determining the number of clusters in the solution, where the Ward linkage method with squared Euclidean distance was used.

The first iteration identified the municipality of Porto Alegre as an outlier, and it remained isolated in a cluster of its own. Iteration on the remaining municipalities showed four or fewer to be the optimal cluster number. The K-means clustering algorithm, which minimizes variance within each group while maximizing variance between groups, was then used to define the members of these four groups. The final clusters are shown in Figure 1.

Table3 - Cluster analysis results

\begin{tabular}{|c|c|}
\hline Municipality & Cluster \\
\hline Caxias do Sul & \multirow{2}{*}{1} \\
\hline Canoas & \\
\hline Viamão & \multirow{5}{*}{2} \\
\hline Alvorada & \\
\hline Sapucaia do Sul & \\
\hline Uruguaiana & \\
\hline Bagé & \\
\hline Pelotas & \multirow{5}{*}{3} \\
\hline Santa Maria & \\
\hline Gravataí & \\
\hline Novo Hamburgo & \\
\hline São Leopoldo & \\
\hline Rio Grande & \multirow{5}{*}{4} \\
\hline Passo Fundo & \\
\hline Santa Cruz do Sul & \\
\hline Cachoeirinha & \\
\hline Bento Gonçalves & \\
\hline
\end{tabular}

The mean values of the positive indicator score percentages for the municipalities contained in each cluster were computed next, and the results are shown in Figure 2. 
Table 4 - Transparency per cluster

\begin{tabular}{|l|l|}
\hline Cluster & Percentage of positive answers \\
\hline 1 & $64 \%$ \\
\hline 2 & $30 \%$ \\
\hline 3 & $55 \%$ \\
\hline 4 & $49 \%$ \\
\hline
\end{tabular}

The results shown in Figure 2 allow the inference that transparency indicators have common profiles within the groups that were formed; this trend is highlighted in two of these clusters. Cluster 1, which consists of the municipalities of Caxias do Sul and Canoas, displays a more significant percentage of positive scores for the indicators as well as higher values for the variables examined in this study (population, GDP at current price, GDP per capita and collected tax revenues), indicating that there may be a relation between disclosing information on the city hall's website and the variables used in this study. Cluster 2 also exhibits this behavior because the group of municipalities belonging to this group has, on average, a lower percentage of positive scores indicators (30\%) and lower values for the variables, especially with regard to GDP at current prices, GDP per capita and collected tax revenues. Moreover, the municipality of Porto Alegre (outlier), which could make up its own separate group because it has positively differentiated values for the variables used in this study, also has the highest percentages of positive indicator scores $(86 \%)$.

\subsection{Transparency Level By Information Indicator}

Joint analysis of the indicators allows the identification of the indicators that had a stronger presence in the analyzed municipalities and those that are still minimally exploited by municipalities. A total of 29 indicators were used, of which four pertain to political representatives, 11 pertain to the management of public resources, five pertain to public resource management actions and nine pertain to participation tools for citizens.

Figure 3 shows the indicators related to information about political representatives. 
Table 5 - Who political representatives are

\begin{tabular}{|l|l|l|}
\hline Indicators & $\begin{array}{l}\% \text { of } \\
\text { positive } \\
\text { scores } \\
\text { negative } \\
\text { scores }\end{array}$ \\
\hline $\begin{array}{l}\text { a) Is there basic information about the mayor: name and/or picture? } \\
\text { b) Is there information about the mayor: biography and/or curriculum } \\
\text { vitae? }\end{array}$ & $39 \%$ \\
\hline $\begin{array}{l}\text { c) Is there basic information about the representatives who make up the } \\
\text { government: names or pictures? }\end{array}$ & $61 \%$ \\
\hline $\begin{array}{l}\text { d) Is there basic information about the representatives who make up the } \\
\text { government: biography and/or curriculum vitae? }\end{array}$ & $22 \%$ & $78 \%$ \\
\hline
\end{tabular}

Figure 3 shows that the mayor's name or picture is found on almost every city hall's website. However, more detailed information, such as the mayor's biography or curriculum vitae is found on fewer city hall websites; seven municipalities detailed this information. The situation is similar in the case of other government representatives, such as municipal secretaries.

Figure 4 refers to the way municipalities handle information related to the management of public resources.

Table 6 - How public resources are managed

\begin{tabular}{|l|l|l|}
\hline Indicators & $\begin{array}{l}\% \text { of } \\
\text { positive } \\
\text { scores }\end{array}$ & $\begin{array}{l}\% \text { of } \\
\text { negative } \\
\text { scores }\end{array}$ \\
\hline $\begin{array}{l}\text { a) Is there information on the power of government bodies, such } \\
\text { as secretariats, local authorities and other entities? }\end{array}$ & $67 \%$ & $33 \%$ \\
\hline $\begin{array}{l}\text { b) Is there information about the composition of these } \\
\text { government bodies? }\end{array}$ & $50 \%$ & $50 \%$ \\
\hline $\begin{array}{l}\text { c) Is there information about these bodies' work chronograms? } \\
\text { d) Are announcements about government acts, such as public } \\
\text { bids, published? }\end{array}$ & $83 \%$ & $17 \%$ \\
\hline
\end{tabular}


e) Is there information about contracts signed by government bodies?

f) Is there information about the Government Plan (GP), Pluriannual Plan, Budgetary Directives Law and Annual Budget Law (Lei de Diretrizes Orçamentárias and Lei Orçamentária Anual)?

g) Is there information about other municipal plans, such as Agenda 21, women, youth engagement, etc.?

h) Is the list of public servants and their salaries published?

i) Are the salaries of elected or commissioned officials published?

j) Is there information about the execution of the municipality's budget?

k) Are the Fiscal and Accounting Statements published?

\begin{tabular}{|l|l|}
\hline $39 \%$ & $61 \%$ \\
\hline $56 \%$ & $44 \%$ \\
\hline $17 \%$ & $83 \%$ \\
\hline $28 \%$ & $72 \%$ \\
\hline $33 \%$ & $67 \%$ \\
\hline $78 \%$ & $22 \%$ \\
\hline $67 \%$ & $33 \%$ \\
\hline
\end{tabular}

The strong presence of information about the publishing of government activities stands out in Figure 4, especially with regard to public bids, information on budget execution, the publishing of fiscal and accounting statements and information on secretariats and government bodies. On the other hand, two indicators were disclosed by only three municipalities each, namely: information on the government's bodies work chronograms, i.e., the planned activities of these bodies, and the existence of municipal outreach plans, mainly, Agenda 21 and engagement with women and youth. The low percentage of the "publishing the list of public servants and their salaries" indicator $(28 \%)$ is also noteworthy. Under the Information Access Law, this is a matter that should be addressed by each municipality to effectively practice information transparency.

Figure 5 addresses the reporting of administration information, which should keep the community informed of activities related to the management of municipal resources, i.e., how municipalities share information with the community in general. 
Table7 - Reports of collective resource management actions

\begin{tabular}{|l|l|l|}
\hline Indicators & $\begin{array}{l}\% \text { of positive } \\
\text { answers }\end{array}$ & $\begin{array}{l}\% \text { of negative } \\
\text { answers }\end{array}$ \\
\hline a) Are news published on the WEB? & $100 \%$ & $0 \%$ \\
\hline $\begin{array}{l}\text { b) Is there information about the activities of members of the } \\
\text { Town Council? }\end{array}$ & $0 \%$ & $100 \%$ \\
\hline $\begin{array}{l}\text { c) Are there reports on the hiring profiles and concessions } \\
\text { signed by the city hall with companies, organizations or } \\
\text { individuals? }\end{array}$ & $11 \%$ & $89 \%$ \\
\hline $\begin{array}{l}\text { d) Is there a transparency website, in accordance with the law? } \\
\text { e) Is information in accordance with the Information Access }\end{array}$ & $56 \%$ & $44 \%$ \\
\hline Law published? & $44 \%$ & $56 \%$ \\
\hline
\end{tabular}

In this group, the indicator "publishing news on the web" stands out as the only attribute found in $100 \%$ of the analyzed city hall websites. This result indicates an interest in publicizing government activities. Figure 5 also shows the indicator with the lowest $(0 \%)$ scores, the existence of information about the activities of Town Councilors. This result may be related to the power structure in Brazil, in which the Executive and Legislative branches are independent and do not disclose information about themselves through the channels of other authorities because they each have their own websites. News about the Town Council appears only on the websites of each city hall's Legislative authority.

Two indicators representative of deficiencies in city hall websites, shown in Figure 5, refer to the existence of transparency websites and the publishing of information required by the Information Access Law. On average, only 50\% of municipalities disclose this information. However, it must be noted that even those that disclose this information in the specifically allotted areas on the city hall's websites still do so incompletely, omitting details required by the legislation, especially in relation to the salaries of public servants.

The final group of indicators, shown in Figure 6, addresses the tools for popular participation and the general disclosure of municipal information. 
Table 8 - Tools that allow for public participation in democratic control

\begin{tabular}{|l|l|l|}
\hline Indicators & $\begin{array}{l}\% \text { of } \\
\text { positive } \\
\text { answers }\end{array}$ & $\begin{array}{l}\% \text { of } \\
\text { negative } \\
\text { answers }\end{array}$ \\
\hline $\begin{array}{l}\text { a) Is there information about the municipality's conditions, such } \\
\text { as population, social, economic, cultural, etc.? }\end{array}$ & $78 \%$ & $22 \%$ \\
\hline b) Is there information about the city's history? & $89 \%$ & $11 \%$ \\
\hline $\begin{array}{l}\text { c) Does the site contain contact information for members of the } \\
\text { government, such as e-mail addresses? }\end{array}$ & $89 \%$ & $11 \%$ \\
\hline d) Is the city hall a member of a social network? & $50 \%$ & $50 \%$ \\
\hline $\begin{array}{l}\text { e) Is information about public participation regularization } \\
\text { provided? }\end{array}$ & $17 \%$ & $83 \%$ \\
\hline $\begin{array}{l}\text { f) Does the site contain information about other participation } \\
\text { mechanisms, such as regional councils, municipal councils, } \\
\text { sectorial councils, etc.? }\end{array}$ & $17 \%$ & $83 \%$ \\
\hline $\begin{array}{l}\text { g) Are instruments for participation in the budget and other } \\
\text { municipal plans offered to the population? }\end{array}$ & $22 \%$ & $78 \%$ \\
\hline $\begin{array}{l}\text { h) Does the site offer a place or information about a place where } \\
\text { citizens can denounce cases of corruption or make complains or } \\
\text { suggestions? }\end{array}$ & $50 \%$ & $50 \%$ \\
\hline $\begin{array}{l}\text { i) Is there information about the contact person responsible for } \\
\text { public relations? }\end{array}$ & $28 \%$ & $72 \%$ \\
\hline
\end{tabular}

Published information about the municipality's history and the presence of contact information for members of the government stand out in Figure 6, with 89\% disclosure of these indicators. With regard to undisclosed indicators, the following stand out: information about public participation regularization and information about other forms of participation such as regional, municipal or sectorial councils. Also noteworthy in Figure 6 is that 50\% of all municipalities are presented on social networks, which may be an important instrument for communication between the community and public entities.

In the sample there are four municipalities: Porto Alegre, Novo Hamburgo, São Leopoldo and Sapucaia do Sul, using participatory budgeting. It is observed that these, Porto Alegre and Novo Hamburgo are among the municipalities with the greatest level of transparency, 
indicating that $50 \%$ of the municipalities that use the participatory budget are more transparent in presenting their website.

\section{Finalizing}

The goal of the present study was to ascertain the level of transparency of administrative information provided by city halls in the south of Brazil by analyzing the presence of a set of indicators on their websites. It must be noted that the websites of the city halls of Porto Alegre, Canoas, Novo Hamburgo and Passo Fundo showed the highest levels of positive scores for the proposed indicators.

Furthermore, it was possible to identify a correlation between positive scores for the indicators and municipal GDP, which suggests that greater municipal economic power might be an important factor in encouraging the authorities to seek greater transparency. Additionally, it can be seen that population, GDP and collected tax revenues are variables that, if jointly analyzed, can be used to define groups of municipalities that display similar behaviors in terms of transparency.

Finally, attention must be given to the concerns of municipalities in relation to presenting information through their websites, particularly the disclosure of actions related to the administration of collective resources. Moreover, the lack of emphasis given to providing the public with tools that allow them to participate in democratic control is noteworthy and confirms the findings of Souza, Rezende and Hardt (2007), who assert that governments have answered with proactive actions that favor the spreading of responsible and effective policies, but still require cultural changes, making it necessary to build new forms of social control and, most importantly, increase the transparency of state actions.

As a proposal for future studies, it is important to broaden the universe of sampled municipalities and acquire a deeper understanding of the reasons that they choose to include or not include some types of information on their websites.

\section{References}

Barbosa, H. (2009). Transparência Pública e Parlamento Eletrônico: A Reforma do Poder Judiciário no Portal do Senado Federal 2000-2004, (Public Transparency and Electronic Parliament: The Reform of Judiciary Power on the Federal Senate's Website 2000-2004). Doctoral Thesis, Methodist University of São Paulo, São Bernardo do Campo, SP, Brasil.

Barros, L. V. (2008). O Estado (In) Transparente: Limites do Direito à Informação Socioambiental no Brasil (The (Un) Transparent State: Limits of the Right to Socio-environmental Information in Brazil). Doctoral Thesis, University of Brasília, Brasília, DF, Brasil.

Cárcaba, A.; García, J. (2008). Determinantes de la divulgación de información contable a través de internet por parte de los gobiernos locales (Determinants of the disclosure of accounting information through the Internet by local governments). Revista Española de 
Financiación y Contabilidad, 137, 63-84.

Cavalcante, R. J. (2008). Transparência do Orçamento Público Brasileiro: exame dos documentos orçamentários da União e uma proposta de estrutura para o Orçamento-Cidadão, Secretaria de Orçamento Federal (Brazilian Public Budget Transparency: examination of budgetary documents of the Union and a structured proposal for the Citizen-Budget, Federal Budget Secretariat).Retrieved on the 30th of March of 2008 from https://www.portalsof.planejamento.gov.br/sof/Premio/2008/Venc2008/.

Controladoria Geral da União (Union General Comptroller), (2012). Orientações para a implementação da Lei de Acesso à Informação nas ouvidorias públicas (Guidelines for implementing the Information Access Law in public ombudsmen). Brasília, DF, Retrieved on the 10th of February of 2012 from www.cgu.gov.br.

Cruz Jr., A. F. da, (2010). Informação, Moeda e Sociedade: uma análise das dimensões informacionais da governança da autoridade monetária no Brasil (Information, Currency and Society: an analysis of the informational dimensions of the monetary authority's governance in Brazil). Doctoral Thesis, University of Brasília, Brasília, DF, Brasil.

Culau, A. A.; Fortis, M. F. de A. (2006). Transparência e controle social na administração pública brasileira: avaliação das principais inovações introduzidas pela Lei de Responsabilidade Fiscal (Transparency and social control in Brazilian public administration: assessment of the main innovations brought by the Fiscal Responsibility Law). Anais Congreso Internacional del CLAD sobre la Reforma del Estado y de La Administración Pública, 11, Ciudad de Guatemala, Guatemala.

Decree n. 5,482, from the 30th of June of 2005, (2005). Rules on the disclosure of data and information by bodies and entities of the federal public administration by means of the world-wide computer network - Internet.

Evans, J. H.; Patton, J. M. (1987). Signalling and monitoring in public sector accounting. Journal of Accounting Research, 25, 130-158.

Fávero, L. P.; Belfiore, P.; Silva, F. L. da; Chan, B. L. (2009). Análise de dados: modelagem multivariada para tomada de decisões (Data analysis: multivariate analysis for decision-making). Rio de Janeiro: Elsevier.

Gallego-Álvarez, I.; Rodríguez-Domínguez, L.; García-Sánchez, I-M. (2010). Are determining factors of municipal E-government common to a worldwide municipal view? An intra-country comparison. Government Information Quarterly, 27, 423-430.

Garcia-Sánchez, I-M.; Frías-Aceituno, J-V.; Rodriguez-Domínguez, L. (2012). Determinants of Corporate Social Disclosure in Spanish Local Governments. Journal of Cleaner Production.

Ingram, R. W.; Dejong, D. V. (1987). The effect of regulation on local government disclosure practices. Journal of Accounting \& Public Policy, 6(4), 245-270.

Laswad, F.; Fisher, R.; Oyelere, P. (2005). Determinants of voluntary internet financial 
reporting by local government authorities. Journal of Accounting and Public Policy, 24, 101-121.

Law n. 12,527, from the 18th of November of 2011, (2011). Rules... Retrieved on the 30th of March of 2012 from http://www.planalto.gov.br/ccivil_03/_Ato2011-2014/2011/Lei/L12527.htm.

Complementary Law n. 101, from the 4th of May of 2000, (2000). Rules... Retrieved on the 12th of March of 2012 from http://www.planalto.gov.br/ccivil_03/leis/LCP/Lcp101.htm.

Martins, G. A.; Theóphilo, C. R. (2009). Metodologia da investigação científica para ciências sociais aplicadas (Scientific investigation methodology for the applied social sciences), 2. ed. São Paulo: Atlas.

Motta, P. R. (2007). A modernização da Administração Pública Brasileira nos últimos 40 anos (Modernisation of Brazilian Public Administration in the last 40 years). Revista de Administração Pública - RAP, Edição Especial Comemorativa 1967-2007, 87-96.

Moon, M. J. (2002). The evolution of E-government among municipalities: Rhetoric or reality? Public Administration Review, 62(4), 424-433.

Nascimento, E. R. (2006). Gestão Pública (Public Administration). São Paulo: Saraiva.

Pires, A. M., Scherer, F. L., Santos, M. B., \& Carpes, A. M. (2013). Transparência da gestão pública municipal: um estudo nos municípios de Santa Maria e Novo Hamburgo / RS. Revista Estudos do CEPE, 38, 131-160, jul./dec.

Platt Neto, O. A.; Cruz, F. da.; Ensslin, S.; Ensslin, L. (2007, January/March). Publicidade e Transparência das Contas Públicas: obrigatoriedade e abrangência desses princípios na administração pública brasileira (Publicity and Transparency in Public Accounts: legal requirements and scope of these concepts in Brazilian public administration). Contabilidade Vista \& Revista, 18(1), 75-94,

Interministerial Ordinance n. 140 from the 16th of March of 2006, (2006). Disciplines the disclosure of data and information by bodies and entities of the Federal Public Administration, by means of the world-wide computer network - Internet, and gives other provisions. Retrieved in the 12th of March of 2012, from http://www.cgu.gov.br/Legislacao/Arquivos/Portarias/Portaria_Interministerial.Pdf.

Prado, O.; Loureiro, M. R. G. (2006). Governo Eletrônico e Transparência: avaliação da publicização das contas públicas das capitais brasileiras (Electronic Government and Transparency: assessment of the publication of public accounts in Brazilian capitals). Alcance, 13(3), 355-372.

Presidência da República (Presidency of the Republic), (2012). Portal da Transparência do Governo Federal (Transparency Website of the Federal Government). Retrieved on the 2nd of February of 2012 from http://www.portaltransparencia.gov.br.

Resolution CFC n. 1,128 of the 21st of November of 2008, (2008). Rules... Retrieved on the 


10th of April of $\quad 2012$ from

http://www.normaslegais.com.br/legislacao/resolucaocfc1128_2008.htm.

Serrano-Cinca, C.; Rueda-Tomás, M.; Portillo-Tarragona, P. (2009). Factors influencing e-disclosure in local public administrations. Environment and Planning C: Government and Policy, 27(2), 355-378.

Souza, A. C. S. de; Rezende, D. A.; Hardt, C. (2007). Estratégia, Planejamento de Municípios e Gestão Metropolitana (Strategy, Municipal Planning and Metropolitan Administration). Revista de Administração e Inovação (RAI), 4(1), 21-39.

\section{Copyright Disclaimer}

Copyright for this article is retained by the author(s), with first publication rights granted to the journal.

This is an open-access article distributed under the terms and conditions of the Creative Commons Attribution license (http://creativecommons.org/licenses/by/3.0/). 